\title{
BELIMBING WULUH (Averrhoa Bilimbi) SEBAGAI SUMBER ENERGI DALAM SEL GALVANI
}

\author{
Sri Suryaningsih ${ }^{1, a}$ \\ ${ }^{1}$ SMA Negeri 1 Manyar \\ Jl. Kayu Raya PPI Manyar Gresik \\ e-mail: asuryafisika61@gmail.com
}

BELIMBING WULUH (Averrhoa Bilimbi) AS ENERGY SOURCE IN GALVANI CELL

\begin{abstract}
Abstrak
Sel Galvani yaitu sel yang menghasilkan arus listrik, terdapat tiga komponen, yaitu anoda, katoda, dan elektrolit. Elektrolit dapat berupa senyawa asam, garam, atau amfoter. Belimbing wuluh (Averrhoa bilimbi) merupakan salah satu buah yang mengandung asam format, sehingga berpotensi untuk menjadi larutan elektrolit. Tujuan penelitian ini antara lain: (1) untuk mengetahui bagaimana pemanfaatan belimbing wuluh (Averrhoa bilimbi) sebagai larutan elektrolit dalam sel Galvani untuk menghasilkan energi listrik, dan (2) untuk mengetahui perbandingan jumlah belimbing wuluh (Averrhoa bilimbi) dan energi listrik yang dihasilkan. Metode yang digunakan adalah metode eksperimental yang menggunakan belimbing wuluh sebagai objek penelitian. Hasil penelitian menginformasikan bahwa satu sistem sel Galvani dapat menghasilkan tegangan dan arus listrik sebesar 0.72 volt dan $0.29 \mathrm{~mA}$. Setelah dilakukan penelitian dapat disimpulkan bahwa belimbing wuluh (Averrhoa bilimbi) dapat dimanfaatkan sebagai larutan elektrolit dalam sistem sel Galvani untuk menghasilkan energi listrik.
\end{abstract}

Kata kunci: Belimbing Wuluh (Averrhoa bilimbi), elektrolit, sel Galvani

\begin{abstract}
A galvanic cell is a kind of cell that produces electric current. A galvanic cell consists of three components, which are an anode, cathode, and electrolyte. The electrolyte can be an acid compound, salt, or amfoter. Star fruit (Averrhoa bilimbi) is a kind of fruits which contains formic acid that can be used as electrolyte solution in the galvanic cell to produce electric current. The purposes of this research were (1) to understand how to use star fruit (Averrhoa bilimbi) as electrolyte solution in a galvanic cell to produce an electric current, and (2) to know the comparison between the amount of star fruit (Averrhoa bilimbi) and the electrical energy produced. The method used in this experiment was an experimental approach with star fruit as the experimental object. The result of this research showed that a galvanic cell system could produce 0.72 volts of electric voltage and $0.29 \mathrm{~mA}$ of electric current. After getting the result of research, it could be concluded that star fruit (Averrhoa bilimbi) could be used as electrolyte solution in a galvanic cell to produce electric current.
\end{abstract}

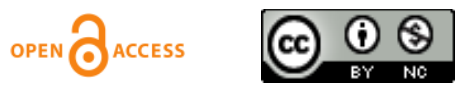


Keywords: Star fruit (Averrhoa bilimbi), electrolyte, galvanic cell

Copyright@2016 Jurusan Fisika FMIPA Universitas Negeri Surabaya

\section{PENDAhUluan}

Belimbing adalah nama Melayu untuk jenis tanaman buah dari keluarga Oxalidaceae, marga Averrhoa. Tanaman belimbing dibagi menjadi dua jenis, yaitu belimbing manis (Averrhoa carambola) dan belimbing asam (Averrhoa bilimbi) atau lazim pula disebut belimbing wuluh. Belimbing wuluh berasal dari Kepulauan Maluku dan menyebar ke seluruh bagian Negara Indonesia [1].

Belimbing wuluh merupakan tumbuhan berjenis pepohonan yang hidup di ketinggian 5-500 meter di atas permukaan laut. Batangnya memiliki ketinggian mencapai \pm 15 meter dengan percabangan yang sedikit. Belimbing wuluh memiliki rasa masam, biji berbentuk gepeng, dan apabila sudah masak airnya banyak. Belimbing wuluh sering disebut juga belimbing sayur atau belimbing asam karena memiliki rasa yang cukup asam dan biasanya digunakan sebagai bumbu masakan atau ramuan jamu dan mengandung banyak zat tannin, saponin, glukosa sulfur, asam format, peroksida, flavonoid, serta triterpenoid.

Larutan yang berupa senyawa asam seperti senyawa asam sulfat, asam oksalat, asam format, dan asam sitrat diketahui merupakan larutan elektrolit. Elektrolit digunakan dalam sistem sel Galvani untuk menghantarkan ion-ion dari anoda menuju katoda sehingga dapat menghasilkan listrik. Belimbing wuluh mengandung cairan asam format, sehingga berpotensi untuk menghasilkan listrik. Seperti yang diketahui, belimbing wuluh memiliki tingkat keasaman tinggi.

Berdasarkan latar belakang yang telah peneliti jelaskan, maka pada penelitian ini peneliti membuat sistem sel Galvani dengan menggunakan belimbing wuluh sebagai bahan alternatif larutan elektrolit untuk menghasilkan listrik.

Tujuan penelitian ini antara lain (1) untuk mengetahui bagaimana pemanfaatan belimbing wuluh sebagai larutan elektrolit dalam sel Galvani untuk menghasilkan energi listrik dan (2) untuk mengetahui perbandingan jumlah belimbing wuluh (Averrhoa bilimbi) dan energi listrik yang dihasilkan.

Manfaat yang diharapkan dalam penelitian ini antara lain (1) memberikan wawasan pengetahuan dan informasi tentang pemanfaatan belimbing wuluh sebagai larutan elektrolit dalam sel Galvani untuk menghasilkan listrik, (2) memberikan inovasi sumber energi listrik alternatif, (3) memberikan pengetahuan kepada masyarakat tentang manfaat belimbing wuluh, dan (4) memberikan ilmu pengetahuan tentang pengolahan belimbing wuluh yang sudah ada sebelumnya.

Menurut Wood [2], reaksi elektrokimia merupakan reaksi oksidasi dimana elektron lepas dan diterima oleh reaktan menuju bahan konduktor seperti logam elektroda. Agar lebih mudah, elektrokimia dapat dibagi menjadi dua bagian, yaitu pertama adalah reaksi kimia yang dihasilkan oleh arus listrik (elektrolisis), dan kedua adalah reaksi kimia yang menghasilkan arus listrik (proses yang terjadi pada baterai).

Ada beberapa metode yang dapat digunakan untuk menyebabkan persebaran ion. Salah satu metode yang umum adalah dengan menggunakan lempengan seng, lempengan tembaga, dan larutan elektrolit. Dalam 
system ini, elektron - dari atom seng akan terlepas, sementara ion $\mathrm{Zn}^{2+}$ yang dihasilkan akan keluar dari lempengan seng dan menyebar di dalam larutan.

$Z n \rightarrow Z n^{+2}+2 e$

Elektron yang diberikan oleh atom seng akan terkumpul pada permukaan lempengan tembaga. Kemudian elektron-elektron tersebut akan bereaksi dengan ion-ion dari atom-atom tembaga.

$\mathrm{Cu}^{+2}+2 e \rightarrow \mathrm{Cu}$

Dalam sistem ini terjadi pergerakan ion-ion negatif menuju lempengan seng dan ion-ion positif menuju lempengan tembaga.

Menurut [3], sel yang menghasilkan arus listrik disebut dengan sel Galvani. Dalam sel Galvani terdapat tiga komponen, yaitu anoda, katoda, dan elektrolit. Anoda berfungsi sebagai elektroda bermuatan negatif dan katoda bermuatan positif. Arus listrik mengalir dari katoda menuju ke anoda. Contoh dari sel Galvani adalah baterai, aki, dan sel bahan bakar (fuel cell).

Baterai adalah suatu sel listrik yaitu suatu alat yang dapat menghasilkan listrik dari reaksi kimia. Pada hakekatnya, suatu baterai terdiri dari dua atau lebih sel yang dihubungkan secara urut atau paralel. Satu sel terdiri suatu elektroda negatif, elektrolit untuk menghantarkan ion, suatu pemisah, juga suatu ion penghantar dan elektroda positif.

Elektrolit dapat berupa cairan (terdiri atas air) atau nonaqueos (tidak terdiri atas air), cairan pasta, atau bentuk padat. Ketika sel dihubungkan dengan suatu beban eksternal atau alat berenergi mesin, elektroda negatif memberikan arus elektron dan diterima oleh elektroda positif [3].

\section{METODE PENELITIAN}

Penelitian ini dilakukan di rumah peneliti pada 29 November 2014. Jenis penelitian ini adalah penelitian eksperimental yang menggunakan belimbing wuluh sebagai objek penelitian. Belimbing wuluh yang digunakan adalah belimbing wuluh segar yang sudah tua atau sudah berwarna hijau kekuningan yang didapt dari daerah Ujung Pangkah, Kabupaten Gresik, sementara teknik pengumpulan data yang digunakan adalah teknik observasi, yaitu suatu teknik pengamatan langsung apa saja yang tejadi di lapangan.

Tahap pertama yang dilakukan dalam pelaksanaan penelitian ini adalah tahap persiapan yaitu mengidentifikasi masalah dan penelusuran pustaka. Tahap kedua adalah merancang penelitian, sementara tahap ketiga adalah tahap eksperimen dan pelaporan hasil yang sebelumnya perlu dilakukan pengambilan data dan analisis data.

Adapun alat dan bahan yang digunakan dalam penelitian ini adalah:

Tabel 1. Daftar Alat dan Bahan

\begin{tabular}{lll}
\hline No & Alat/Bahan & Jumlah \\
\hline 1 & Belimbing wuluh & $1 \mathrm{~kg}$ \\
2 & Pelat seng & $15 \mathrm{~cm} \mathrm{x} 3 \mathrm{~cm}$ \\
3 & Pelat tembaga & $15 \mathrm{~cm} \mathrm{x} 3 \mathrm{~cm}$ \\
4 & Kabel & 2 meter \\
5 & Gelas plastik & 5 buah \\
6 & Alat parut & 1 buah \\
7 & Mangkok plastik & 2 buah \\
8 & Gelas ukur & 1 buah \\
9 & Gunting & 1 buah \\
10 & Cutter & 1 buah \\
11 & Selotip & 1 buah \\
\hline
\end{tabular}

\section{Alur Kerja}

Sebelum digunakan, belimbing wuluh dicuci terlebih dahulu, kemudian dihaluskan dan diambil sarinya. Sari belimbing wuluh 
dituangkan ke dalam gelas plastik. Setiap gelas plastik berisi $100 \mathrm{~mL}$ sari belimbing wuluh. Pelat tembaga dan seng yang dibutuhkan berukuran $3 \mathrm{~cm} \quad \mathrm{x} \quad 3 \mathrm{~cm}$ masing-masing sebanyak 5 buah, kemudian setiap pelat tembaga dihubungkan dengan pelat seng dengan menggunakan kabel sepanjang $3 \mathrm{~cm}$. sementara di sisi pelat yang lain dihubungkan dengan kabel sepanjang 15 $\mathrm{cm}$. Setiap rangkaian pelat tembaga dan seng dimasukkan ke dalam gelas plastik yang telah berisi sari belimbing wuluh.

Skema prosedur eksperimen sebagai berikut:

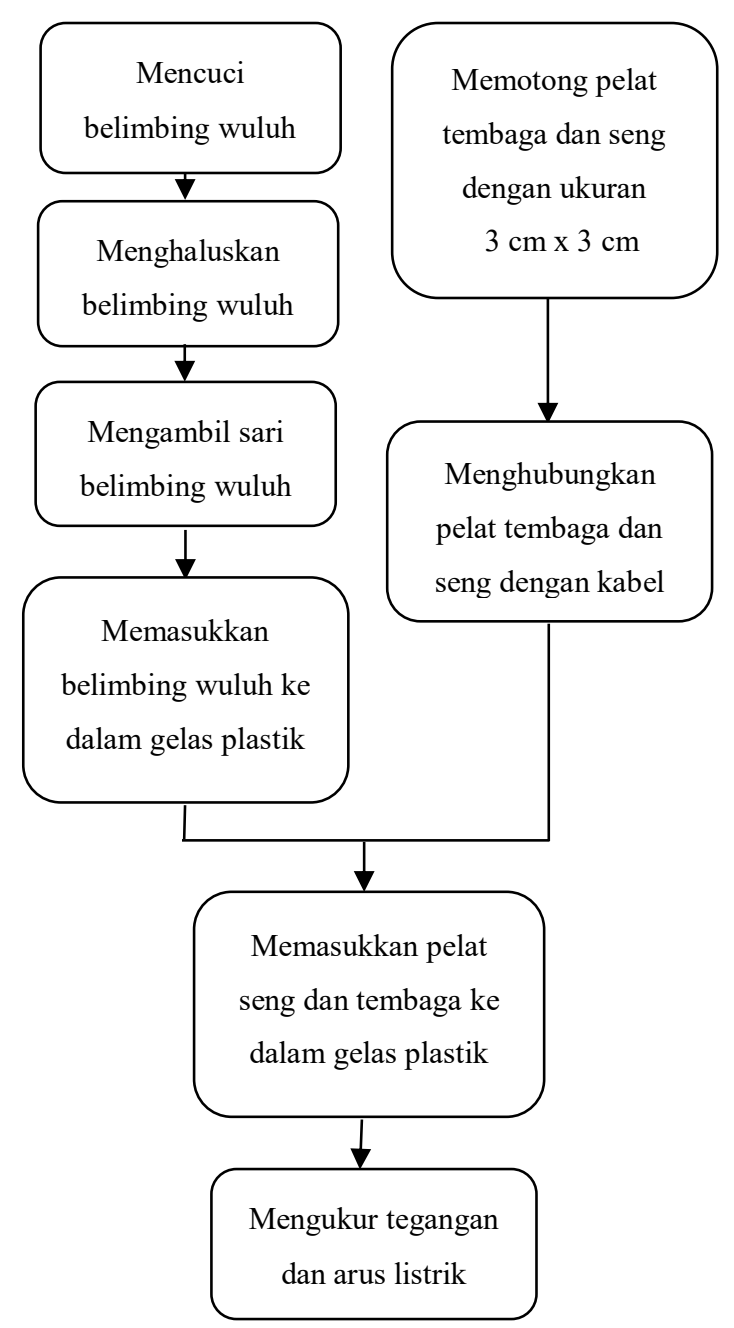

Gambar 1. Skema Prosedur Eksperimen

Pada percobaan pertama dilakukan pengukuran tegangan dan arus listrik pada setiap sistem dengan menggunakan multimeter analog. Kabel yang terhubung ke pelat seng merupakan kutub positif, sementara kabel yang terhubung ke pelat tembaga merupakan kutub negatif. Sebelum melakukan pengukuran, alat ukur yang digunakan dikalibrasi terlebih dahulu agar hasil pengukuran lebih akurat. Kemudian kutub positif sistem dihubungkan dengan kabel merah pada multimeter, sementara kutub negatif dihubungkan dengan kabel hitam. Pengukuran pertama adalah pengukuran tegangan, dilanjutkan dengan pengukuran arus listrik.

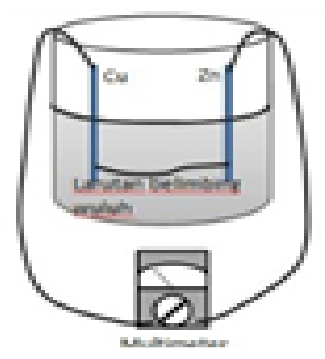

\section{Gambar 2. Rangkaian Percobaan Pertama}

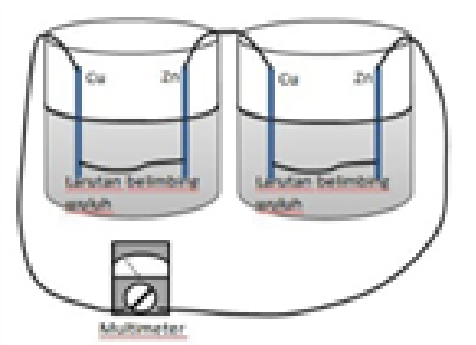

Gambar 3. Rangkaian Percobaan Kedua.

Pada percobaan kedua dilakukan pengukuran tegangan dan arus dengan memanipulasi jumlah sistem yang akan diukur tegangan dan arusnya. Pertama mengukur tegangan dan arus pada satu sistem, kemudian mengukur tegangan dan arus pada dua sistem yang disusun secara seri, begitu seterusnya hingga pengukuran tegangan dan arus pada lima sistem yang disusun secara seri.

Berikut merupakan gambar pengukuran tegangan dan arus listrik pada cairan belimbing wuluh. 


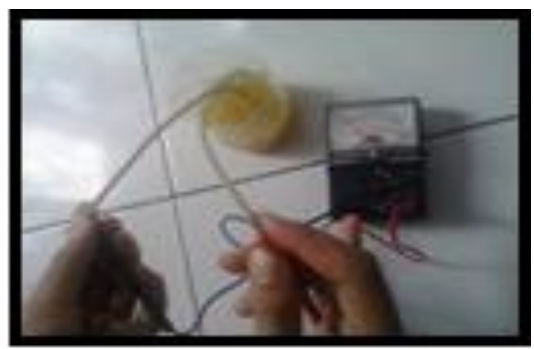

Gambar 4.

Percobaan Pertama

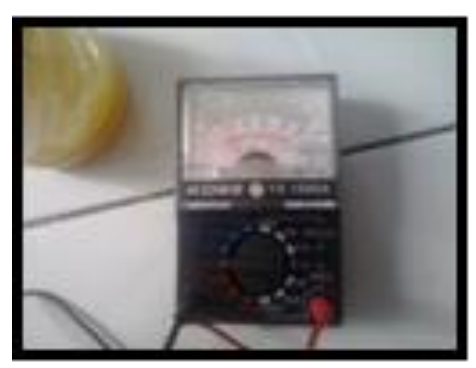

Gambar 5. Penunjukan Besar Tegangan

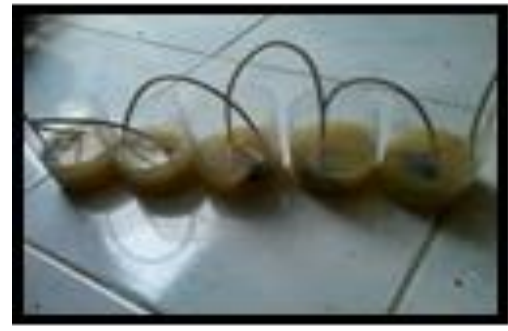

Gambar 6.

Percobaan Kedua

\section{HASIL PENELITIAN DAN DISKUSI}

Pada percobaan pertama dilakukan pengukuran tegangan dan arus listrik pada setiap sistem sel Galvani berisi $100 \mathrm{~mL}$ larutan belimbing wuluh. Pengukuran dilakukan dengan menggunakan multimeter analog. Hasil yang didapatkan disajikan dalam Tabel 2.

Berdasarkan data hasil percobaan pertama diketahui bahwa dua gelas pertama menghasilkan tegangan listrik yang sama sebesar 0.6 volt dengan arus listrik yang berbeda, yaitu 0.32 dan $0.30 \mathrm{~mA}$. Kemudian gelas ketiga, keempat, dan kelima menghasilkan tegangan listrik yang sama sebesar 0,8 volt dan arus listrik yang berbeda-beda, yaitu berturut-turut sebesar $0.25 \mathrm{~mA}, 0.31 \mathrm{~mA}$, dan $0.29 \mathrm{~mA}$.

Tabel 2. Data Hasil Percobaan Pertama

\begin{tabular}{cccc}
\hline $\begin{array}{c}\text { Gelas } \\
\text { ke }\end{array}$ & $\begin{array}{c}\text { Volume } \\
(\mathrm{ml})\end{array}$ & $\begin{array}{c}\text { Tegangan } \\
(\mathrm{V})\end{array}$ & $\begin{array}{c}\text { Arus } \\
(\mathrm{mA})\end{array}$ \\
\hline 1 & 100 & 0,6 & 0,32 \\
2 & 100 & 0,6 & 0,30 \\
3 & 100 & 0,8 & 0,25 \\
4 & 100 & 0,8 & 0,31 \\
5 & 100 & 0,8 & 0,29 \\
\hline
\end{tabular}

Data hasil percobaan pertama telah membuktikan bahwa larutan belimbing wuluh dapat berfungsi sebagai elektrolit dalam sistem sel Galvani dengan menggunakan pelat seng sebagai anoda dan pelat tembaga sebagai katoda. Ion-ion negatif pada pelat seng mengalir melalui larutan belimbing wuluh menuju pelat tembaga sehingga menghasilkan energi listrik.

Kemudian untuk satu sistem sel Galvani dengan pelat seng dan tembaga berukuran 3 $\mathrm{cm}$ x $3 \mathrm{~cm}$ serta $100 \mathrm{~mL}$ larutan belimbing wuluh dapat menghasilkan tegangan rata-rata sebesar 0.72 volt dan arus rata-rata sebesar $0.29 \mathrm{~mA}$.

Pada percobaan kedua, dilakukan pengukuran tegangan dan arus listrik pada satu hingga lima sistem sel Galvani yang disusun secara seri. Berikut merupakan data hasil percobaan kedua seperti terlihat pada Tabel 3 berikut.

Tabel 3. Data Hasil Percobaan Kedua

\begin{tabular}{cccc}
\hline No. & Volume $(\mathrm{ml})$ & Tegangan $(\mathrm{V})$ & Arus $(\mathrm{mA})$ \\
\hline 1 & $1 \times 100$ & 0,6 & 0,32 \\
2 & $2 \times 100$ & 1 & 0,54 \\
3 & $3 \times 100$ & 1,4 & 0,70 \\
4 & $4 \times 100$ & 2 & 0,93 \\
5 & $5 \times 100$ & 2,8 & 1,18 \\
\hline
\end{tabular}

Berdasarkan data hasil percobaan kedua diketahui bahwa satu sistem sel Galvani 
dengan menggunkan pelat seng sebagai anoda, pelat tembaga sebagai katoda, dan $100 \mathrm{~mL}$ larutan belimbing wuluh sebagai elektrolit diketahui menghasilkan tegangan listrik sebsar 0.6 volt. Kemudian untuk dua system sel Galvani yang disusun secara seri menghasilkan tegangan listrik sebesar 1 volt. Tiga sistem sel Galvani yang disusun secara seri ini menghasikan tegangan listrik sebesar 1.4 volt, sementara untuk empat dan lima sistem Galvani yang disusun secara seri menghasilkan tegangan listrik sebesar 2 volt dan 2.8 volt. Data yang diperoleh kemudian diolah dan dapat disimpulkan bahwa setiap penambahan satu sistem sel Galvani yang disusun secara seri akan menambah tegangan listrik sebesar 0.56 volt.

Selain dilakukan perhitungan tegangan listrik rat-rata, dilakukan pula perhitungan ketelitian pengukuran. Berdasarkan hasil perhitungan, didapatkan ketelitian pengukuran tegangan sebesar 0.97 atau 97\%. Taraf ketelitian dan hubungan besar tegangan listrik terhadap volume larutan belimbing wuluh dapat dilihat pada Gambar 7.

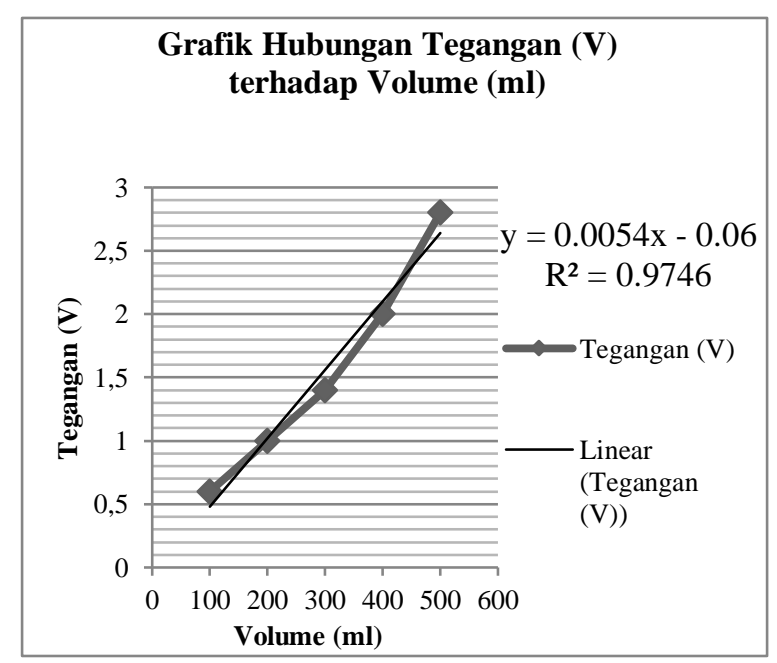

Gambar 7. Grafik Hubungan Tegangan (V) terhadap Volume Belimbing Wuluh (ml).

Berdasarkan data hasil percobaan kedua diketahui pula bahwa satu sistem sel Galvani dengan menggunakan pelat seng sebagai anoda, pelat tembaga sebagai katoda dan 100 $\mathrm{mL}$ larutan belimbing wuluh sebagai elektrolit dihasilkan arus listrik sebesar 0.32 mA. Kemudian untuk dua sistem sel Galvani yang disusun secara seri menghasilkan arus listrik sebesar $0.54 \mathrm{~mA}$. Tiga sistem sel Galvani yang disusun secara seri menghasilkan arus listrik sebesar $0.70 \mathrm{~mA}$, sementara untuk empat dan lima sistem sel Galvani yang disusun secara seri menghasilkan arus listrik sebesar $0.93 \mathrm{~mA}$ dan $1.18 \mathrm{~mA}$. Data yang diperoleh kemudian diolah dan didapat bahwa setiap penambahan satu sistem sel Galvani yang disusun secara seri akan menambah arus listrik sebesar 0.24 $\mathrm{mA}$.

Selain dilakukan perhitungan arus listrik rata-rata, dilakukan pula perhitungan ketelitian pengukuran arus. Berdasrkan hasil perhitungan, didapatkan ketelitian pengukuran arus adalah 0.99 atau 99\%. Taraf ketelitian dan hubungan besar arus listrik terhadap volume larutan belimbing wuluh dapat dilihat pada Gambar 8 .

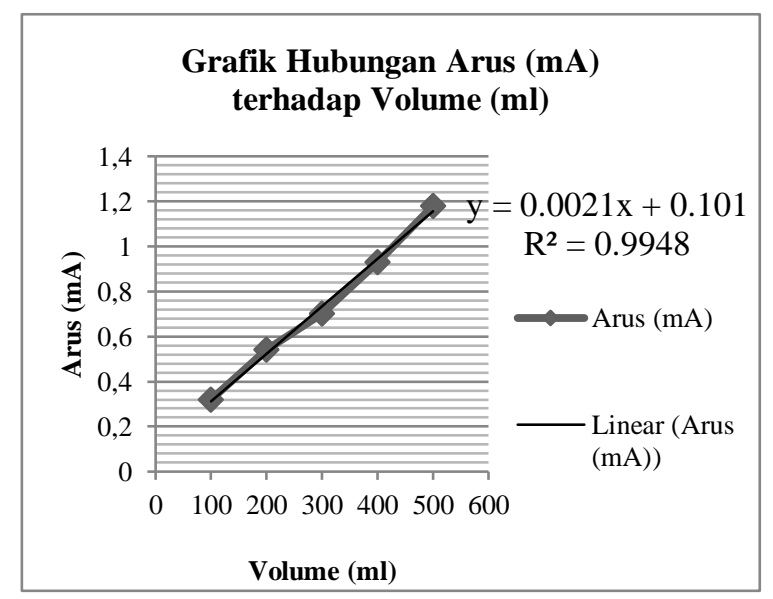

Gambar 8. Grafik Hubungan Arus (mA) terhadap Volume Belimbing Wuluh (ml).

\section{KESIMPULAN}

Dari hasil penelitian data di atas, diperoleh beberapa kesimpulan sebagai berikut: (1) 
cara pemanfaatan belimbing wuluh sebagai larutan elektrolit dalam sel Galvani untuk menghasilkan energi listrik dilakukan melalui eksperimen sistem sel Galvani yang terdiri atas pelat seng sebagai anoda dan pelat tembaga sebagai katoda; (2) perbandingan jumlah belimbing wuluh dan energi listrik yang dihasilkan dari $100 \mathrm{~mL}$ larutan belimbing wuluh sebagai elektrolit dapat menghasilkan tegangan sebesar 0.72 volt dan arus listrik sebesar $0.29 \mathrm{~mA}$; serta (3) setiap penambahan satu sistem sel Galvani yang dirangkai secara seri akan menambah tegangan listrik sebesar 0.56 volt dan menambah arus listrik sebesar $0.24 \mathrm{~mA}$.

\section{Saran}

Adapun saran yang berkaitan dengan hasil penelitian adalah pemanfaatan belimbing wuluh sebagai larutan elektrolit yang menghasilkan listrik sebaiknya digunakan sebagai inovasi sumber energi listrik alternatif dan pengolahan belimbing wuluh sebagai bahan alternatif laruan elektrolit dalam sel Galvani untuk menghasilkan energi listrik supaya lebih dikembangkan.

\section{DAFTAR PUSTAKA}

[1] Gendrowati F. TOGA: Tanaman Obat Keluarga. Padi. Jakarta; 2010.

[2] Wood J.H. Fundamentals of College Chemistry. New York: Harper \& Row Publisher; 1964.

[3] Riyanto. Elektrokimia dan Aplikasinya. Yogyakarta: Graha Ilmu; 2013.

[4] Rahayu I. Praktis Belajar Kimia untuk Kelas XII. Jakarta: Pusat Perbukuan, Departemen Pendidikan Nasional; 2009.

[5] Muara, JA. Sistem Telemetri Untuk Mendeteksi Posisi Robot Line Tracer Menggunakan TLP 433,92-RLP 433,92. Inovasi Fisika Indonesia. 2014; 3(3). Terdapat pada: http://jurnalmahasiswa.unesa.ac.id/index.php/ inovasi-fisika-indonesia/article/view/9926/ba ca-artikel

[6] Tim Penulis MPK Bahasa Indonesia. Menulis Ilmiah: Buku Ajar Bahasa Indonesia MPK Bahasa Indonesia. Surabaya: Unesa University Press; 2014. 